\title{
School leaders' and teachers' work with national test results: Lost in translation?
}

Ann Elisabeth Gunnulfsen, 1凶

Phone +4797759928

Email a.e.gunnulfsen@ils.uio.no

1 Department of Teacher Education and School Research, University of Oslo, Blindern, Postboks 1099, 0317 Oslo, Norway

\section{Abstract}

Studies have shown that school leaders are important in work with largescale policy reforms in schools. However, the issue of how school leaders and teachers discuss and enact policy is understudied. This article explores the discursive processes in school leaders' and teachers' policy enactment as they construct responses to policy. The data consists of video recordings and observation of leadership meetings and teacherteam meetings. A critical discourse analytical approach combined with perspectives of policy enactment as a process of interpretation serve as analytical concepts. The findings indicate the school leaders act more as narrators and enthusiasts, while the deputy managers and teacher-team leaders are more messengers and enforcers. The teachers mostly keep the discursive role as critics and preventers of 'overburdening.' A main argument is that the policy expectation of using national test results as a tool to develop school quality and student learning seems to be lost in translation.

\section{Keywords}

Data use

Discursive roles

National testing

Policy actors

Policy enactment 


\section{Introduction}

Neo-liberal models and language have gained status on national and local levels in the Norwegian educational context. Concepts like accountability, choice, and competition have become a part of the Norwegian discourse and policy of education (Aas et al. 2016; Lindblad et al. 2002; Møller 2009; Møller and Skedsmo 2013). The Norwegian context is worthy of analysis because experts have defined the accountability policies in Norway as less strict than in countries with stronger neo-liberal policies, such as the USA and England (Mausethagen 2013). This article provides a closer investigation of the practices and roles of school leaders and teachers in this less-strict context when they are interpreting and translating national policy expectations in their work with improving student learning in reading and numeracy.

AQ1

Researchers have stated that the relatively recent introduction of national testing in Norway has contributed to changes in schools and resulted in the establishment of new organizational routines (Aasen et al. 2015; Mausethagen et al. 2016). Key questions emerge concerning how Norwegian school principals initiate local work using large-scale student results and how they motivate teachers to take an active part in this. Accountability policies rest on the assumption that results from standardized tests will be used to make decisions about classroom practice, and researchers have contributed to our understanding of how these policy demands put strong pressure on schools (Ball et al. 2012; Hall 2013; Hardy 2014; Mintrop and Sunderman 2009). While many studies on accountability policies have focused on teachers and their role in developing teaching practice (e.g., Ingram et al. 2004; Mausethagen and Granlund 2012), other studies have focused on how school leadership plays the key role (e.g., Anderson et al. 2010; Robinson 2011; Timperley 2011). Although these accountability studies may be complementary, a pattern emerges of either studying the role of teachers or school leaders exclusively (Diamond and Spillane 2004). It is evident that teachers' and leaders' collaboration with colleagues at all organizational levels influences how they interpret, adapt, and enact policy messages in the 
school and the classroom (Coburn 2001; Spillane 1999). Hence, we need to know more about what is happening at the discursive level among school leaders and teachers.

The reported study aims to identify and discuss the discursive processes in school leaders' and teachers' policy enactment as they construct responses to policy by examining how they talk and how they position themselves. Based on observations and extensive video recordings of leader meetings and teacher-team meetings in two lower secondary schools, the following research questions guide the study: (a) How do school leaders and teachers position themselves in their interpretation and translation of national testing policies? (b) In what ways does school leaders' and teachers' language reflect their enactment of national testing policies?

The next section begins by presenting the analytical framework, the empirical context, and the research design before moving on to presenting the findings.

\section{Theoretical perspectives and analytical tools}

\section{Conceptualizing leadership and policy enactment}

I took as a point of departure that leadership is embedded in the relations that exist between role holders and not the specific roles. All members of an organization can influence others by using resources provided in their role; thus, school leadership is not necessarily synonymous with a position and may come from school principals, teachers, and others (Foster 1986; Møller et al. 2007; Ogawa and Bossert 1995). In particular, I drew upon Sørhaug (1996) who has emphasized that leadership as a relation is a living social process of power and trust that the leaders both are given and must take. It is a vertical relationship that is open at both ends. (Leaders get and take power and trust both from above and below) (Sørhaug 1996, p. 45, author's translation).

In this study, I observed how leadership and power relations among school leaders and teachers influenced each other in work with the process of translating and negotiating new national policy expectations. This article also heeded Ball et al.'s (2012) call to take local contexts seriously in efforts to understand why policies are enacted differently in seemingly similar schools. Too often, research on policy implementation has taken for 
granted the meaning of policy itself. Policy texts simply cannot be implemented straightforwardly; rather, they must be translated from texts to action, put into practice, and seen in relation to history and context (Ball et al. 2012, pp. 8-15). When school leaders and teachers read policy documents on national testing, they learn what, why, and when new policies are meant to take place. However, these texts rarely tell school leaders or teachers exactly how work with national test results should happen.

Teachers and school leaders play different roles regarding parents, media, and community, and the roles occur in various locations (e.g., classroom, teacher break room, parents' meeting, principal's office). As such, enactment is likely to diverge because translation and negotiation of policy usually take place in different arenas as well.

\section{Typology of policy actors}

Inspired by the typology of "policy actors/positions which are involved in making meaning of and constructing responses to policy" (Ball et al. 2012, p. 49), one step in the analysis was to identify the different types of roles embedded in the school leaders' and teachers' policy translation work (Table 1). Ball et al. (2012) noted that the positions of policy actors (left column) are not necessarily attached to specific individuals and people may move between these roles in different aspects of their policy work (right column) in their interactions with colleagues.

\section{Table 1}

Overview of 'policy actors' and their 'policy work'

\begin{tabular}{|l|l|}
\hline Policy actors & Policy work \\
\hline Narrators & Interpretation, selection, and enforcement of meanings \\
\hline Entrepreneurs & Advocacy, creativity, and integration \\
\hline Transactors & Accounting, reporting, supporting, and facilitating \\
\hline Enthusiasts & Investment, creativity, satisfaction, and career \\
\hline Translators & Production of texts, artifacts, and events \\
\hline Critics & Monitoring of management, providing counter-discourses \\
\hline $\begin{array}{l}\text { Adapted from Ball et al. (2012, p. 49). Copyright } 2012 \text { by [Copyright holder]. } \\
\text { Reprinted with permission }\end{array}$
\end{tabular}


Policy actors

Receivers
Policy work

Coping, defending, and dependency

Adapted from Ball et al. (2012, p. 49). Copyright 2012 by [Copyright holder]. Reprinted with permission

\section{AQ2}

The typology is developed within an English educational context which means a context featuring strong pressure to govern education through data use (Ozga 2009). This differs from the Norwegian context, where actors in schools experience less accountability pressure. The typology served merely as a tool for my analysis of how school leaders' and teachers' policy positions appeared in their interpretation of national testing policies in a Norwegian context. Hence, other types of policy work might appear such as the work of school leaders and teachers as evaluators. Moreover, school leaders and teachers might hold shifting roles in their policy work by acting as critics in some contexts and enthusiasts in others.

\section{Discursive roles and competing discourses}

In addition to the typology of policy actors, a discourse analytical approach has inspired the analysis (Fairclough 2013). The simplified approach to discourse analysis functioned as a tool to explore how teachers and school leaders position themselves on certain policies and towards each other in their interpretation and translation of policies. I critically examined teachers' and school leaders' joint policy-talk about national testing and the work with improving student learning in reading and numeracy to answer questions about what issues were discussed and how the issues were discussed. Of concern was how language and discursive parts of the language were used to make apparent interpretations and translations of policies, how the language and discursive parts appeared in different roles and events, and how power was exercised through the chains of events (Fairclough 2003).

Ball (1994) defined policy discourses as "ways of talking about and conceptualizing policy" (p. 109). The discursive processes of school leaders and teachers can be discussed in light of the different types of relationships, roles, and engagements that are embedded in the process of interpretation and translation. 


\section{Methodological considerations}

I based this study on observations and video recordings of school leaders and teachers in two lower secondary schools (Brown Hill and Blue Mountain) ${ }^{2}$ located in the same municipality. ${ }^{3}$ School- and municipality documents functioned as secondary contextual data. Case studies provide opportunities to understand phenomena in their real-life contexts (Yin 2009). In this instance, a two-case study approach allowed me to investigate the perspectives of two seemingly similar schools within the same municipality and to find similar or contrasting results for predicted reasons (Yin 2009). In the sections below, I will first outline the national context as a background for the study and then describe the criteria for selecting the schools. Finally, I will describe the process of data collection, coding, and analysis.

\section{The Norwegian context}

The assessment system in Norway includes national testing in grades 5, 8, and 9 , and is described as holding both formative and summative aspects of student assessment (Norwegian Directorate for Education and Training 2011). The primary and lower secondary schools report to the municipality level, although the systems to support and follow up schools vary.

Likewise, schools located in the same municipality differ in their practices. The national tests are conducted early in the fall semester with the intention that schools will use the results in their formative assessments to improve student learning in the basic skills of reading and numeracy throughout the school year.

\section{School context and selection criteria}

I began my search for a municipality by examining their websites for information on their work with national tests and quality development. I selected the target municipality based on their information of being successful in this work. I selected the schools based on statistics of their national test results published on the municipality's website. The two schools had seemingly similar regarding structures of organization and meetings. Their municipality had established a national and local reputation over the previous three years for above-average results on the national tests. These facts and knowledge of the schools had the potential to facilitate access to the schools, on the assumption that these schools 
would be willing to share their engagement and practices.

Both schools had approximately 350-400 students, 30-35 teachers, and a leadership team of two and three deputy managers ${ }^{4}$ and the principal (Table 2). Brown Hill's teachers had worked at the school for more than 15 years on average, and the principal described the school culture and practice as "traditional." Blue Mountain's teachers had worked there for 5-8 years on average, and the faculty can be characterized as "young." However, the principal explained that the school's pedagogical practice had a long history of being progressive. Both schools had similar student populations in terms of having overall native Norwegian speakers and students from medium- to high-income families (Table 3 ).

\section{Table 2}

Overview of participating schools and informants

\begin{tabular}{|c|c|c|c|}
\hline School & Leader team & $\begin{array}{l}\text { Teacher } \\
\text { team 9th } \\
\text { grade }\end{array}$ & General information \\
\hline \multirow{6}{*}{$\begin{array}{l}\text { Blue } \\
\text { Mountain }\end{array}$} & $\begin{array}{l}\text { Rebecca } \\
\text { (principal) }\end{array}$ & $\begin{array}{l}\text { Rosa (deputy } \\
\text { manager) }\end{array}$ & 400 students, 8 th -10 th grade \\
\hline & $\begin{array}{l}\text { Rosa (deputy } \\
\text { manager) }\end{array}$ & $\begin{array}{l}\text { Synne } \\
\text { (teacher } \\
\text { team-leader) }\end{array}$ & $\begin{array}{l}\text { Leader-team meeting twice a } \\
\text { week, } 2 \mathrm{~h}\end{array}$ \\
\hline & $\begin{array}{l}\text { Ronny } \\
\text { (deputy } \\
\text { manager) }\end{array}$ & $\begin{array}{l}\text { Bergljot } \\
\text { (teacher) }\end{array}$ & $\begin{array}{l}\text { Teacher-team meeting twice a } \\
\text { week, } 2 \mathrm{~h}\end{array}$ \\
\hline & \multirow{3}{*}{$\begin{array}{l}\text { Reinhard } \\
\text { (deputy } \\
\text { manager) }\end{array}$} & $\begin{array}{l}\text { Arne } \\
\text { (teacher) }\end{array}$ & $\begin{array}{l}\text { Pedagogical leader-team meeting } \\
\text { once a week, } 2 \mathrm{~h} \text { (principal, } \\
\text { deputy managers and teacher } \\
\text { team leaders) }\end{array}$ \\
\hline & & $\begin{array}{l}\text { Maria } \\
\text { (teacher) }\end{array}$ & \\
\hline & & $\begin{array}{l}\text { Aslak } \\
\text { (teacher) }\end{array}$ & \\
\hline \multirow{3}{*}{$\begin{array}{l}\text { Brown } \\
\text { Hill }\end{array}$} & $\begin{array}{l}\text { Gina } \\
\text { (principal) }\end{array}$ & $\begin{array}{l}\text { Åsmund } \\
\text { (teacher } \\
\text { team-leader) }\end{array}$ & 350 students, 8 th -10 th grade \\
\hline & $\begin{array}{l}\text { Gary (deputy } \\
\text { manager) }\end{array}$ & $\begin{array}{l}\text { Hedvig } \\
\text { (teacher) }\end{array}$ & $\begin{array}{l}\text { Leader-team meeting once a } \\
\text { week, } 2 \mathrm{~h}\end{array}$ \\
\hline & $\begin{array}{l}\text { Greta (deputy } \\
\text { manager) }\end{array}$ & $\begin{array}{l}\text { Norbert } \\
\text { (teacher) }\end{array}$ & $\begin{array}{l}\text { Teacher-team meeting twice a } \\
\text { week, } 2 \mathrm{~h}\end{array}$ \\
\hline
\end{tabular}




\begin{tabular}{|c|c|c|c|}
\hline \multirow[t]{8}{*}{ School } & \multirow[t]{8}{*}{ Leader team } & $\begin{array}{l}\text { Teacher } \\
\text { team 9th } \\
\text { grade }\end{array}$ & General information \\
\hline & & $\begin{array}{l}\text { Anitra } \\
\text { (teacher) }\end{array}$ & \\
\hline & & $\begin{array}{l}\text { Suzanna } \\
\text { (teacher) }\end{array}$ & \\
\hline & & $\begin{array}{l}\text { Hjalmar } \\
\text { (teacher) }\end{array}$ & \\
\hline & & $\begin{array}{l}\text { Helmer } \\
\text { (teacher) }\end{array}$ & \\
\hline & & $\begin{array}{l}\text { Anne Marie } \\
\text { (teacher) }\end{array}$ & \\
\hline & & $\begin{array}{l}\text { Berta } \\
\text { (teacher) }\end{array}$ & \\
\hline & & $\begin{array}{l}\text { Kristine } \\
\text { (teacher) }\end{array}$ & \\
\hline
\end{tabular}

Table 3

Corpus data Blue Mountain and Brown Hill

\begin{tabular}{|c|c|c|c|}
\hline School & $\begin{array}{l}\text { Video-recordings } \\
\text { ("self- } \\
\text { conducted") }\end{array}$ & $\begin{array}{l}\text { Observation and } \\
\text { informal } \\
\text { conversations }\end{array}$ & $\begin{array}{l}\text { Documents both } \\
\text { schools }\end{array}$ \\
\hline \multirow{4}{*}{$\begin{array}{l}\text { Blue } \\
\text { Mountain }\end{array}$} & $32 \mathrm{~h}$ & $15 \mathrm{~h}$ & $\begin{array}{l}\text { Public online } \\
\text { information about } \\
\text { national testing }\end{array}$ \\
\hline & $\begin{array}{l}8 \text { leader-team } \\
\text { meetings }\end{array}$ & $\begin{array}{l}3 \text { leader-team } \\
\text { meetings }\end{array}$ & $\begin{array}{l}\text { School results } \\
\text { published online }\end{array}$ \\
\hline & \multirow{2}{*}{$\begin{array}{l}8 \text { teacher-team } \\
\text { meetings }\end{array}$} & $\begin{array}{l}2 \text { teacher-team } \\
\text { meetings }\end{array}$ & \multirow{2}{*}{$\begin{array}{l}\text { The school's online } \\
\text { documents about } \\
\text { focus-areas and local } \\
\text { plans }\end{array}$} \\
\hline & & 2 plenary meetings & \\
\hline \multirow{3}{*}{$\begin{array}{l}\text { Brown } \\
\text { Hill }\end{array}$} & $8 \mathrm{~h}$ & $5 \mathrm{~h}$ & \\
\hline & $\begin{array}{l}2 \text { leader-team } \\
\text { meetings }\end{array}$ & $\begin{array}{l}2 \text { leader-team } \\
\text { meetings }\end{array}$ & $\begin{array}{l}\text { Information on wall } \\
\text { boards }\end{array}$ \\
\hline & $\begin{array}{l}2 \text { teacher-team } \\
\text { meetings }\end{array}$ & $\begin{array}{l}1 \text { teacher-team } \\
\text { meeting }\end{array}$ & $\begin{array}{l}\text { Emails and the } \\
\text { school's web-page }\end{array}$ \\
\hline
\end{tabular}


I chose the grade 9 teacher team explicitly because of the municipality's expectations regarding the school's contribution to students' learning to generate noticeable improvement in test results from grade 8 to grade 9. The principal and the deputy managers formed the leader team in each school. The leader team met regularly outside of the whole-staff and teacher-team meetings. In addition, observations of a pedagogical team at Blue Mountain offered some background to the data and analysis. ${ }^{5}$ The teacher-team leaders were not regarded as formal leaders in the school organization.

\section{Data}

I conducted the study in the spring semester and throughout October in 2015. Data consisted of a range of sources, such as observation and video recording of meetings, ${ }^{6}$ emails, school plans, municipality documents, a formal meeting with the superintendent, and informal conversations with teachers, deputies, and principals before and after meetings. The meetings primarily concerned work with improving student learning, planning for the next teaching period and the whole school year, and work with national test results. I considered meetings on these topics to be particularly important to study in terms of teachers' and school leaders' collaborative enactment of work with national test results. Therefore, it was important to gather the video footage in the fall, when the school conducted the national tests and made plans for the school year.

In the spring of 2015, I observed about $20 \mathrm{~h}$ of leader-team meetings, teacher-team meetings, and whole-staff teacher meetings. The bulk of observation hours occurred at Blue Mountain, where I was given carte blanche to observe and participate in all meeting types. At Brown Hill, I had to arrange the observation of meetings beforehand, and all observations occurred in leader-team meetings and teacher-team meetings in grade 9. No observation was conducted in plenary meetings at Brown Hill.

I have emphasized the video data from the teacher-team meetings and leader-team meetings in both schools, as these provide the most intensive view of the topic studied. These videos provided a view of school leaders' and teachers' talk about work with national test results in reading and numeracy, and they represented instances where enactment was most 
prominent. Throughout the fall of 2015, I obtained approximately $40 \mathrm{~h}$ of video recordings of teacher-team meetings and school-leader meetings in the two schools. In total, the observation data and video data consisted of approximately $60 \mathrm{~h}$. I informed the school leaders and teachers in person about the aim of the study regarding enactment of work with national test results. The schools (deputy managers and teacher-team leaders) took responsibility for conducting the recordings of all the meetings. Blue Mountain recorded mostly all leader-team meetings and teacher-team meetings from the first week in August throughout October. Brown Hill recorded all the meetings with national testing on the agenda in the same period, resulting in Blue Mountain producing more than two-thirds of the video data. However, I chose an equal number of statements from both schools.

\section{Analysis}

I analyzed the data to reveal sensitive viewpoints in what Fairclough (1992) defined as "intertextuality" (p. 270). These viewpoints would be the school leaders' and teachers' choice of words (especially the use or changes in use of subjects and verbs like "we think", "they should", "you are", "I will") and the intertextuality in the talk (Fairclough 1992, p. 272). For example, a teacher offered a general suggestion for practice: "I think we should read more aloud with the students." The teacher did not mention the students with the poor results; rather, she stated what she thought would help the students in general.

In my analysis of discursive roles, I further focused on binary oppositions. The construction of such binary oppositions is a common discursive strategy for negotiating difference, which represents a general polarization principle. In terms of language use, it is reflected in the pairs of terms used to communicate positive self-representations and negative otherrepresentations. Binary oppositions produce hierarchies of meanings and support constructions of 'the other' through categories of 'us' and 'them' (MacLure 2003). An example of binary opposition would occur if one teacher stated that "we do not want to do what they say," meaning that "we" are the teacher team and "they" are someone else (e.g., the leadership team). In summary, the selected excerpts represented what Fairclough (1995) described as tension points; moments of difficulty by language-inuse. This selection criterion allowed me a more comprehensive analysis of 
situated meanings (Gee 2014), and it also informed the length of the excerpts. Table 4 presents the steps of analysis as part of the coding.

Table 4

Steps of analysis

\begin{tabular}{|c|c|c|c|}
\hline \multicolumn{2}{|l|}{ Aim } & Tools of analysis & $\begin{array}{l}\text { Empirical } \\
\text { research guestions }\end{array}$ \\
\hline $\begin{array}{l}1 \text { st } \\
\text { reading }\end{array}$ & $\begin{array}{l}\text { To obtain an } \\
\text { overview of } \\
\text { situations of when } \\
\text { and how school } \\
\text { leaders and teachers } \\
\text { in the two schools } \\
\text { discussed and } \\
\text { planned for activities } \\
\text { related to national } \\
\text { test results }\end{array}$ & $\begin{array}{l}\text { Focusing on choice of } \\
\text { words: When and how } \\
\text { the talk about national } \\
\text { testing occurred in the } \\
\text { total video material }\end{array}$ & $\begin{array}{l}\text { When and how do } \\
\text { school leaders and } \\
\text { teachers interpret } \\
\text { and translate } \\
\text { national testing } \\
\text { policies? How do } \\
\text { they talk about } \\
\text { work with national } \\
\text { test results? }\end{array}$ \\
\hline $\begin{array}{l}2 \text { nd } \\
\text { reading }\end{array}$ & $\begin{array}{l}\text { To identify how the } \\
\text { participants } \\
\text { positioned } \\
\text { themselves towards } \\
\text { each other in their } \\
\text { interpretation and } \\
\text { translation of } \\
\text { policies of national } \\
\text { testing }\end{array}$ & $\begin{array}{l}\text { Focusing on modalities } \\
\text { and binaries: How the } \\
\text { use of words with } \\
\text { regard to suggestions in } \\
\text { planning of activities } \\
\text { and placing } \\
\text { responsibilities } \\
\text { regarding improving } \\
\text { student learning occur }\end{array}$ & $\begin{array}{l}\text { In what ways do } \\
\text { school leaders' and } \\
\text { teachers' language } \\
\text { reflect the } \\
\text { interpretation and } \\
\text { translation of } \\
\text { policy of national } \\
\text { test results? }\end{array}$ \\
\hline \multirow[t]{2}{*}{$\begin{array}{l}3 \text { rd } \\
\text { reading }\end{array}$} & \multirow{2}{*}{$\begin{array}{l}\text { To synthesize } \\
\text { variations between } \\
\text { the two schools } \\
\text { individual and } \\
\text { collective talk } \\
\text { occurring as } \\
\text { responses to the use } \\
\text { of test results in } \\
\text { local work with } \\
\text { improving student } \\
\text { learning }\end{array}$} & \multirow{2}{*}{$\begin{array}{l}\text { Focusing on and } \\
\text { comparing moments of } \\
\text { difficulty indicated by } \\
\text { school leaders' and } \\
\text { teachers' talk about } \\
\text { future plans and } \\
\text { understanding of work } \\
\text { with national test } \\
\text { results for improving } \\
\text { student learning }\end{array}$} & $\begin{array}{l}\text { How do school } \\
\text { leaders and } \\
\text { teachers position } \\
\text { themselves among } \\
\text { each other in their } \\
\text { interpretation and } \\
\text { translation of } \\
\text { national test } \\
\text { results? }\end{array}$ \\
\hline & & & $\begin{array}{l}\text { What are the } \\
\text { similarities and } \\
\text { differences in } \\
\text { school leaders' and } \\
\text { teachers' } \\
\text { collectively talk? }\end{array}$ \\
\hline
\end{tabular}

The coding and analysis of the observations and the video recordings can be characterized as inductive because codes were developed through multiple viewings and readings of the material. The emerging approach of the process of analysis concentrated on the interpretation and translation done by the participating school leaders and teachers when they discussed 
their work with national testing in reading and numeracy. I conducted the further steps in a more deductive manner, combining perspectives of enactment (Ball et al. 2012) with a discourse analytical approach to make the enactment more transparent (Jørgensen and Phillips 1999).

\section{Validity, limitations, and ethical considerations}

The study's limitations include the data collection method, sample size and representativeness. Using video recording as data collection has advantages and disadvantages. Video recording can enhance the credibility of an observation by permanently capturing non-verbal and verbal interactions simultaneously (Caldwell and Atwal 2005). The recordings can be played back repeatedly, allowing verbal and non-verbal interactions to be observed and analyzed in detail. Additionally, I have discussed the analysis and possible interpretations with other researchers as a method for communicative validity (Kvale and Brinkmann 2009). The overall consistency in the observations across the teacher teams and leader teams may strengthen the confidence in the trustworthiness of data (Lincoln and Guba 1985; Porter 2007).

In terms of limitations, informants that are self-reporting by conducting video recording of themselves might create the Hawthorne-effect (McCambridge et al. 2014). In other words, school leaders and teachers may behave or perform better or differently than when not recorded. Even if the effect diminishes over time, this is an important bias issue to consider. Additionally, while I was not present or on site in any phase of the meetings, participants may have had the 'feeling' or notion of the researcher's presence every time the video recorder was turned on.

Beyond these limitations concerning video recordings, the samples were small, which leads to an uncertainty of representativeness that usually means that the study can provide only suggestive answers to the research questions (Maxwell 2012). The disparity in the amount of data from the two schools may further complicate the trustworthiness of the analysis. However, it can be regarded as a finding that Blue Mountain willingly allowed on-site observations and video recordings while Brown Hill was more reserved.

To uphold ethical considerations, I paid attention to confidentiality and 
security of digital data. I sought informed consent of participation and anonymized all data.

In the next section, I will present the key findings based on the observation data and the video recordings.

\section{Findings}

Data from leader-team meetings and teacher-team meetings provided rich material for identifying the discursive roles in school leaders' and teachers' policy enactment as they constructed responses to policy. Three main discursive themes emerged in their discursive talk: (a) the principals as narrators and enthusiasts, (b) deputy managers and teacher-team leaders as messengers and enforcers, and (c) teachers as critics and preventers of 'overburdening.' In the following, the excerpts are presented in tables with lines and numbers identifying and separating the speakers.

\section{Analysis of discursive roles}

The analysis begins with the principals' discursive roles in the interpretation of the school's focus on instruction with reading and numeracy as the basic skills tested in the Norwegian national tests. Thereafter, I proceed with a more fine-tuned presentation of the relations between principals, deputy managers, and teachers, and their discursive roles in the translation of policy expectations.

The principals as narrators and enthusiasts

According to Ball et al. (2012), narrators do their policy work by interpretation, selection, and enforcement of meanings. The school leaders seemed determined in their talk when interpreting and translating policies. At Blue Mountain, the leader team discussed several dimensions of teaching and learning and how the school overall was supposed to understand their plans, practices, and activities. The principal Rebecca introduced topics in the leader-team meeting and dominated the talk, and relations of power prevailed through the quantity of talk. The amount of talk represented enthusiasm, investment, and enforcement. The issues were focused on teaching practices regarding the school's work with reading and numeracy. In Table 5, principal Rebecca (1) tells the deputy managers in the leader-team meeting that she wants them to encourage pedagogical 
discussions in the teacher team about basic skills that are essential in all subjects, holding a discursive role as a narrator:

\section{Table 5}

The narrator at Blue Mountain

\begin{tabular}{|c|c|c|}
\hline $\begin{array}{l}\text { Transcript } \\
\text { line }\end{array}$ & Speaker & Talk/text \\
\hline (1) & $\begin{array}{l}\text { Rebecca } \\
\text { (principal) }\end{array}$ & $\begin{array}{l}\text { Well, I really think that reading and English are the } \\
\text { obvious basic skills [...] Basic skills should be } \\
\text { something you learn through the subjects, as well as } \\
\text { basic skills should help you learn better in every } \\
\text { subject. And reading is that kind of skill. You may } \\
\text { stop the teaching in the subject Norwegian, but you } \\
\text { still learn how to read. And reading and writing are } \\
\text { such basic skills. And oral skills. Maybe digital } \\
\text { skills are like this as well. But not numeracy. } \\
\text { Numeracy is actually just mathematics, I think. [...] } \\
\text { because you cannot remove the teaching in the math } \\
\text { lessons, and have the student learn about numeracy } \\
\text { anyway. I mean that basic skills in numeracy totally } \\
\text { fall out of the concept. It is just a kind of } \\
\text { curriculum-policy, theoretical 'thing.' That does not } \\
\text { necessarily mean that we are not supposed to put } \\
\text { effort in math-teaching and numeracy as a basic } \\
\text { skill }\end{array}$ \\
\hline (2) & $\begin{array}{l}\text { Rosa } \\
\text { (deputy) }\end{array}$ & $\begin{array}{l}\text { Yes. Well. The practical math. That fits into all } \\
\text { subjects, don't you think? }\end{array}$ \\
\hline (3) & $\begin{array}{l}\text { Rebecca } \\
\text { (principal) }\end{array}$ & $\begin{array}{l}\text { Yes, I agree. But the question is whether you can } \\
\text { learn social science without being able to do math? } \\
\text { The answer is yes, you can. But can you learn social } \\
\text { science without being able to read? The answer is } \\
\text { no. }[\ldots]\end{array}$ \\
\hline (4) & $\begin{array}{l}\text { Reinhard } \\
\text { (deputy) }\end{array}$ & $\begin{array}{l}\text { Exactly! The basic skill of numeracy has become a } \\
\text { kind of political issue. Because we have failed in the } \\
\text { international assessments as TIMSS and PISA }\end{array}$ \\
\hline (5) & $\begin{array}{l}\text { Rebecca } \\
\text { (principal) }\end{array}$ & $\begin{array}{l}\text { Fair enough. So what do you think: What is a good } \\
\text { balance between pushing and steering the teachers } \\
\text { in these issues? }\end{array}$ \\
\hline (6) & $\begin{array}{l}\text { Rosa } \\
\text { (deputy) }\end{array}$ & $\begin{array}{l}\text { I think that the teachers feel that it is okay that we } \\
\text { hold the steering wheel, that we kind of systematize } \\
\text { and keep hold of the main points. I believe they } \\
\text { appreciate it. And speaking of which: We have to set } \\
\text { up the schedules for conducting the national tests, } \\
\text { and we need to decide which rooms are the best to } \\
\text { use because the school is open and rooms are rented } \\
\text { out every evening }\end{array}$ \\
\hline
\end{tabular}


Rebecca asserts that numeracy is not connected to the 'ordinary' subjects in the same way as reading and English. Rosa tries to balance the point by arguing for the functions of practical mathematics (2). Rebecca maintains her position about numeracy: that the national policy intention of connecting numeracy to every other subject is a failure (3). Reinhard agrees with Rebecca and talks about how international policy and global tests like Trends in International Mathematics and Science Study (TIMSS) and Program for International Student Assessment (PISA) have influenced educational issues about basic skills (4). The use of "we" in his statement presumably means "all students or schools nationwide." Rebecca turns Reinhard's contribution into a question of how to present the discussion to the teachers. Rebecca's question functions as both an encouragement for the teachers, but also as a demand (5). The initiative is built on her previous dominant argument. Finally, Rosa sums up by confirming that the teachers appreciate that the leaders "hold the steering wheel" (6).

The talk in Table 6 reveals an example of how the school leaders at Blue Mountain interpreted the school's use of national test results in the leaderteam meeting. 
Table 6

The enthusiast at Blue Mountain

\begin{tabular}{|c|c|c|}
\hline $\begin{array}{l}\text { Transcript } \\
\text { line }\end{array}$ & Speaker & Talk/text \\
\hline (1) & $\begin{array}{l}\text { Rebecca } \\
\text { (principal) }\end{array}$ & $\begin{array}{l}\text { Actually, we can use national test results to detect } \\
\text { students who need help. That is important. And the } \\
\text { parents are asking about them [the results]; How } \\
\text { good is this school? And how do you do it? And } \\
\text { then they will be surprised that we have a different } \\
\text { approach than the other schools }\end{array}$ \\
\hline (2) & $\begin{array}{l}\text { Reinhard } \\
\text { (deputy) }\end{array}$ & $\begin{array}{l}\text { Behold, it is a bit hairy. Don't you think that we } \\
\text { actually are supposed to use national test results to } \\
\text { improve the quality of our education!? (Laughter) }\end{array}$ \\
\hline (3) & $\begin{array}{l}\text { Rebecca } \\
\text { (principal) }\end{array}$ & $\begin{array}{l}\text { We must not say that we do this [the national tests] } \\
\text { because we have to. It would sound like whining. } \\
\text { We must not even dream of saying that! National } \\
\text { testing is actually one way to be able to discover } \\
\text { students' development in many subjects at once, } \\
\text { and this is the one approach that we have not done } \\
\text { before, so I cannot claim that this is not helpful. So } \\
\text { we need to ask the question: what is it that this } \\
\text { [low-performing] student did not get from your } \\
\text { reading instruction? }\end{array}$ \\
\hline
\end{tabular}

Rebecca's statement (1) is built on two dimensions with making use of national test results to inform teaching practice. She first points to how the results may identify low-performing students. Second, she focuses on the parents' involvement in the school's total results. Rebecca confirms that national test results as helpful in detecting students who need help. Her talk illuminates her position as an enthusiast within a dimension of investment and creativity. She believes that the results might mirror the prior knowledge of the group of low-performing students. Reinhard (2) comments on Rebecca's statement and ensures that Rebecca really does not mean that the test results function as tools to improve school quality. They even find it somewhat amusing. Rebecca, however, states that it is of utmost importance that the school does not reveal a negative attitude about national testing. When Rebecca finally says that "we need to ask the question," she reveals a form of enthusiastic talk about "we" as all teachers and leaders together (3). This enthusiastic talk illuminates a policy enactment which seeks to interpret and translate policies by communicating and transmitting them into (teachers') practice. 
At Brown Hill, as shown in Table 7, the discursive role of the principal is represented in principal Gina's linguistic approach to deputy manager Åsmund in a leader-team meeting.

Table 7

The narrator at Brown Hill

\begin{tabular}{|c|c|c|}
\hline $\begin{array}{l}\text { Transcript } \\
\text { line }\end{array}$ & Speaker & Talk/text \\
\hline (1) & $\begin{array}{l}\text { Gina } \\
\text { (principal) }\end{array}$ & $\begin{array}{l}\text { Here is a list of all the assignments (points at the } \\
\text { screen where the information about national tests is } \\
\text { published), which says something about what type } \\
\text { of assignments the students will get [when taking } \\
\text { the national tests]. Whether it's a-if it is about } \\
\text { interpretation... or...elaboration... right? So the } \\
\text { teachers can find each one of them. One is supposed } \\
\text { to move forward in these pages but it is a bit } \\
\text { awkward... }\end{array}$ \\
\hline (2) & $\begin{array}{l}\text { Asmund } \\
\text { (deputy) }\end{array}$ & Yes, it takes quite some time \\
\hline (3) & $\begin{array}{l}\text { Gina } \\
\text { (principal) }\end{array}$ & $\begin{array}{l}\text { But what's good is that, from now on, if you want to } \\
\text { check up on one single student, you enter here } \\
\text { [points on the screen] to check each student's result } \\
\text { [...] because that's what's interesting. And the } \\
\text { courses [intensive courses in reading and numeracy] } \\
\text { are already planned on the basis of the expected } \\
\text { results... And now I have planned that we, together, } \\
\text { shall take a look at the guidelines here [...] And so I } \\
\text { remind you that it is very important that you look for } \\
\text { improvement in the results. And then it is very } \\
\text { important that you share your students' results and } \\
\text { the improvement. Right? So that it can be used as } \\
\text { tools for further teaching and instruction. It is } \\
\text { important. Right? And yes, [...] well [...] we will } \\
\text { talk more about this next week, and the week after. } \\
\text { [...] The question is: what does this mean for our } \\
\text { school's further instruction? Right? }\end{array}$ \\
\hline (4) & $\begin{array}{l}\text { Asmund } \\
\text { (deputy) }\end{array}$ & $\begin{array}{l}\text { To follow up afterwards you mean? Yes, yes, that's } \\
\text { important }\end{array}$ \\
\hline
\end{tabular}

Gina uses the words "so the teachers can find" to indicate that Åsmund is supposed to convey this information to teachers in the teacher-team meeting (1). Åsmund confirms the difficulties (2). In the next excerpt, Gina uses the word "you," presumably meaning the teachers, including Åsmund. This creates a binary between Gina (as the leader) and 'them'. However, she concludes by using the word "we" when saying "we will talk more 
about this." (3). Gina might mean "we" as the leader team or "we" as all the teachers and leaders collaboratively. Åsmund confirms Gina's information once again (4). This situation represents a general polarization principle in terms of language used to communicate binary oppositions that produce hierarchies of meanings and power. Gina contributes to the construction of 'the other' through categories of 'us' and 'them' in her discursive role as narrator, but also as an interpreter concerning how she wants the teachers to work with national test results. Her argument is emphasized in the leader-team meeting shown in Table 8.

\section{Table 8}

The enthusiast at Brown Hill

\begin{tabular}{|c|c|c|}
\hline $\begin{array}{l}\text { Transcript } \\
\text { line }\end{array}$ & Speaker & Talk/text \\
\hline (1) & $\begin{array}{l}\text { Åsmund } \\
\text { (deputy) }\end{array}$ & Yes, it is actually the gain that is interesting here \\
\hline (2) & $\begin{array}{l}\text { Gina } \\
\text { (principal) }\end{array}$ & $\begin{array}{l}\text { And }[\ldots] \text { Yes, that you discuss this together in the } \\
\text { team and as a team- -how the results can be used. } \\
\text { And that all of you on the team put this issue on the } \\
\text { agenda. The guidelines from the authorities tell us a } \\
\text { lot about what we can do when the results are } \\
\text { available. In the monitoring of student performance, } \\
\text { that is. It is the teachers that are assessing the } \\
\text { reading tests and even if they have to use discretion, } \\
\text { compared to what the students might have been } \\
\text { thinking when giving their answers }\end{array}$ \\
\hline (3) & $\begin{array}{l}\text { Åsmund } \\
\text { (deputy) }\end{array}$ & So the single teacher shall check this...? \\
\hline (4) & $\begin{array}{l}\text { Gina } \\
\text { (principal) }\end{array}$ & $\begin{array}{l}\text { Yes! [...] What a shame that Gary was preoccupied } \\
\text { now that we are discussing these important issues! } \\
\text { Well, never mind. Let's talk about which rooms we } \\
\text { are going to use for the tests, and who's going to put } \\
\text { all the computers ready for national testing. And } \\
\text { most of all: How will we know if the iPads can be } \\
\text { used for national testing? }\end{array}$ \\
\hline
\end{tabular}

In the next meeting, Gina continues her information about using the test results by discussing "the teachers," "us," "we," and "they" $(2,4)$. It seems as if she wants to mitigate the issue of power by including "us" when talking about guidelines from the authorities. However, the "they" is prominent and diminishes a convincing representation of "we." The principal's discursive roles as enthusiast and narrator occur in the 
forefront, and the power relations between the principal and 'the others' are dominating. Throughout this meeting, she takes a persuasive role when communicating her interpretations of the policy intentions about making use of national test results. In the above example, I find two prominent discursive roles of principals: the role of the principal Gina as the narrator and enthusiast who instructs the focus of discussions in the teacher-team meetings. The other is the role of the principal Rebecca as the narrator and enthusiast who designs the focus of teacher-team discussions.

The deputy managers and teacher-team leaders as messengers and enforcers

The previous excerpts show that principals in the leader-team meetings design the conversation and instruct them to focus on various discussions. When the principal holds the discursive role of narrator, it is left more to the deputy managers to translate these narratives into practice. Table 9 illuminates how teachers in the teacher-team meeting at Brown Hill try to grasp the intention from the authorities about making use of national tests, and how the teacher-team leader Åsmund tries to hold on to the principal's instruction about using the guidelines from the authorities.

\section{Table 9}

The enforcer at Brown Hill

\begin{tabular}{|c|c|c|}
\hline $\begin{array}{l}\text { Transcript } \\
\text { line }\end{array}$ & Speaker & Talk/text \\
\hline (1) & $\begin{array}{l}\text { Åsmund } \\
\text { (deputy) }\end{array}$ & $\begin{array}{l}\text { Here, you can see the webpage where we can find... } \\
\text { (standing beside the smart board) }\end{array}$ \\
\hline (2) & $\begin{array}{l}\text { Hedvig } \\
\text { (teacher) }\end{array}$ & $\begin{array}{l}\text { I think that actually reading jointly aloud together } \\
\text { with the students - that is very important! }\end{array}$ \\
\hline (3) & $\begin{array}{l}\text { Anitra } \\
\text { (teacher) }\end{array}$ & $\begin{array}{l}\text { Yes, I agree, I would like us to discuss the } \\
\text { importance of reading the text aloud in class. Yes, } \\
\text { we simply read textbooks aloud, too. Digital reading } \\
\text { is not the same }\end{array}$ \\
\hline (4) & $\begin{array}{l}\text { Åsmund } \\
\text { (deputy) }\end{array}$ & $\begin{array}{l}\text { And then there are those types of assignments UDIR } \\
\text { [Directorate of Education] say that we can use } \\
\text { (pointing at the smart board) }\end{array}$ \\
\hline (5) & $\begin{array}{l}\text { Norbert } \\
\text { (teacher) }\end{array}$ & $\begin{array}{l}\text { (Interrupting, talking while simultaneously raising } \\
\text { his hand). Shall we simply inform the students, and } \\
\text { provide these assignments as homework for them or } \\
\text { are we supposed to do the assignments together with } \\
\text { our students? Should we spend time on this at the } \\
\text { school or? }\end{array}$ \\
\hline
\end{tabular}




\begin{tabular}{|c|c|c|}
\hline $\begin{array}{l}\text { Transcript } \\
\text { line }\end{array}$ & Speaker & Talk/text \\
\hline (6) & $\begin{array}{l}\text { Åsmund } \\
\text { (deputy) }\end{array}$ & $\begin{array}{l}\text { What do you think, yourselves? We are supposed to } \\
\text { make students familiar with the type of assignments } \\
\text { and the text-types... }\end{array}$ \\
\hline (7) & $\begin{array}{l}\text { Berta } \\
\text { (teacher) }\end{array}$ & $\begin{array}{l}\text { We've got.... We went through the results with them } \\
\text { (the students) last year }\end{array}$ \\
\hline (8) & $\begin{array}{l}\text { Åsmund } \\
\text { (deputy) }\end{array}$ & Yeah, we did, right? \\
\hline (9) & $\begin{array}{l}\text { Norbert } \\
\text { (teacher) }\end{array}$ & $\begin{array}{l}\text { Yes, we went through the assignments in advance, } \\
\text { we... And we told the students these are the kind of } \\
\text { tasks you get in the samples }\end{array}$ \\
\hline (10) & $\begin{array}{l}\text { Åsmund } \\
\text { (deputy) }\end{array}$ & $\begin{array}{l}\text { Let's see: What do you think, folks? Should we do } \\
\text { this at school this year? In which lessons? Or should } \\
\text { we expect the students to do this at home? }\end{array}$ \\
\hline
\end{tabular}

With her comment in Table 9, Hedvig (2) interrupts Åsmund as he is currently pointing at the smart board, telling the teachers how to make use of the webpage to learn about the student results (1). Hedvig seems to suddenly remember that she would like to talk about how she uses joint reading in her reading instruction. Anitra supports Hedvig (3), but Åsmund continues pointing at the smart board, returning focus to the instruction from Gina regarding how to make use of the student assignments (4).

Åsmund continues talking when Norbert (5) interrupts about practical issues concerning how and when these exercises should be performed. This is another example the teachers asking questions that the teacher-team leader must answer or negotiate about the understanding of the policy initiative being discussed. Because Åsmund does not have the answer, he turns the question back to all the teachers (6). It seems that Åsmund tries to make the teachers responsible for understanding the policy intentions put forth on the webpage from the authorities. Berta (7) seems to be trying to help Åsmund in this situation. Åsmund (8) seems relieved, as Norbert (9) confirms last year's practice as well. Åsmund tries to summarize (10), still signaling that he wants the teachers to take responsibility for approaching this policy intention. It seems that he uses the word 'we' to show that the teacher-team leader, and the teachers are all together in this.

The talk in Table 10 reveals how the teachers in the teacher-team meeting 
take more responsibility and become narrators when discussing practicalities about conducting the national tests. They both enforce and advocate meanings about national testing policies:

Table 10

The messenger at Brown Hill

\begin{tabular}{|c|c|c|}
\hline $\begin{array}{l}\text { Transcript } \\
\text { line }\end{array}$ & Speaker & Talk/text \\
\hline (1) & $\begin{array}{l}\text { Åsmund } \\
\text { (deputy) }\end{array}$ & $\begin{array}{l}\text { [...] Gina has given me a plan for the students } \\
\text { offered to take intensive courses. This counts for } \\
\text { those students who have not improved in the English } \\
\text { subject this year. And then, dates are set for } \\
\text { conducting the national tests, and these are, of } \\
\text { course, only suggestions from the leadership. That is, } \\
\text { it is possible to change dates }\end{array}$ \\
\hline (2) & $\begin{array}{l}\text { Anitra } \\
\text { (teacher) }\end{array}$ & Can we decide this for ourselves? \\
\hline (3) & $\begin{array}{l}\text { Åsmund } \\
\text { (deputy) }\end{array}$ & $\begin{array}{l}\text { It is the teachers who are teaching the students in the } \\
\text { actual period that are responsible for conducting the } \\
\text { tests }\end{array}$ \\
\hline (4) & $\begin{array}{l}\text { Berta } \\
\text { (teacher) }\end{array}$ & $\begin{array}{l}\text { Does everybody have to take the tests at the same } \\
\text { time? In that case, we must not forget that it is } \\
\text { domestic science on Wednesdays. If we do, we are in } \\
\text { serious trouble }\end{array}$ \\
\hline (5) & $\begin{array}{l}\text { Åsmund } \\
\text { (deputy) }\end{array}$ & $\begin{array}{l}\text { No, and if they have to, we will not have any } \\
\text { problems with it, either } \\
\text { I think Greta has reserved computers for this. I'll } \\
\text { check it out, and if she hasn't, then this will in any } \\
\text { case be overridden }\end{array}$ \\
\hline
\end{tabular}

In the above talk, we find that Åsmund introduces (1) the plan for conducting the national tests, stating that the plan is only a suggestion from "the leadership" without defining who the "leadership" is and whether he is a part of it. Anitra's question (2) signals that the word "we" refers to someone other than the "leadership." Åsmund answers (3) that this is up to the teachers that have the students on the specific dates. Berta has a comment (4) about how things might go terribly wrong if the tests collide with 'her' subject (domestic science). The teacher dominance on facilitating practical solutions seems to be more prominent in respect to allocating the time allotted for the tests. Thus, teachers take greater responsibility when discussing solutions related to practicalities. Berta 
expresses an identity far removed from national testing policies.

In Table 11, the teacher-team leader Synne and deputy manager Rosa at Blue Mountain discuss how they want to approach the parents when revealing the school's results on the national tests. The discussion takes place in a teacher-team meeting.

\section{Table 11}

The messenger at Blue Mountain

\begin{tabular}{|c|c|c|}
\hline $\begin{array}{l}\text { Transcript } \\
\text { line }\end{array}$ & Speaker & Talk/text \\
\hline (1) & $\begin{array}{l}\text { Synne } \\
\text { (team } \\
\text { leader) }\end{array}$ & $\begin{array}{l}\text { (Opens up her laptop and looks at Rosa as she begins } \\
\text { to speak) I think we need to discuss the parents } \\
\text { meeting and what we want to present to the parents } \\
\text { from the national test results. When it comes to the } \\
\text { national tests, the information to teachers says: } \\
\text { "national tests give us information about the school's } \\
\text { input from } 8 \text { th grade." [...]. This is about the anchor- } \\
\text { tasks }\end{array}$ \\
\hline (2) & $\begin{array}{l}\text { Rosa } \\
\text { (deputy) }\end{array}$ & Yes? \\
\hline (3) & $\begin{array}{l}\text { Synne } \\
\text { (team } \\
\text { leader) }\end{array}$ & $\begin{array}{l}\text { I wish that it [the information from the authorities] } \\
\text { would rather say something like "the tests give us } \\
\text { some information about the school's input." I mean } \\
\text { this because it is important to illuminate and justify } \\
\text { that we [the teachers and the school] also do other } \\
\text { things that that most probably have influenced the } \\
\text { outcome [the national test results] }\end{array}$ \\
\hline (4) & $\begin{array}{l}\text { Rosa } \\
\text { (deputy) }\end{array}$ & $\begin{array}{l}\text { I totally agree! It is so good that we have more than } \\
\text { one eye on these things. We mustn't be 'blinded' by } \\
\text { these results only }\end{array}$ \\
\hline
\end{tabular}

Synne (1) uses the word "we," which can be understood as an invitation to jointly discuss the issue in the exact meeting that is about to start in a few minutes. Synne is careful in the way she presents her matter and uses the word "wish" when talking about how the school leaders at Blue Mountain might want to present and justify the students' test results (3). The issue of presenting test results can be regarded as policy work, and Synne obviously does not want to be too dominant in her argumentation, whereas Rosa completely agrees with her (4) and acknowledges Synne's initiative.

Synne positions herself towards the deputy manager and speaks on behalf 
of the teachers as a means of being heard in a matter of educational policy. The power perspective in representing all the teachers seems prominent. In this case, Synne functions both as facilitator and critic. Synne even holds a narrator role in negotiating meaning between the leadership team and the teachers. Synne's policy position is an example of multiple roles appearing in schools' local work with national testing policies; significantly, this examination of shifting roles is lacking in Ball et al.'s (2012) typology.

As this excerpt reveals, the delivery work with information about national test results functions in two ways, not only from the 'top' down to the teachers, but from the teachers at the 'bottom' and up through the teacherteam leaders or deputy managers. Synne's initiative represents just as much the role of a preventer of 'overburdening' the teachers' workload, as well as critiquing the authorities' information about national test results. In other words, she plays the discursive role of a 'connector' between the formal leaders and the teachers, as she is touring the policy discourse and the professional discourse between the two groups of policy actors.

\section{The teachers as critics and preventers of overburdening}

At Brown Hill, the discursive role of the teachers in the teacher-team meetings functions as much the role of a preventer of 'overburdening' the teachers' workload. In Table 12, the teachers are responding to the principal's demands for using the test results to enhance student learning.

\section{Table 12}

The critics at Brown Hill

\begin{tabular}{|l|l|l|}
\hline $\begin{array}{l}\text { Transcript } \\
\text { line }\end{array}$ & Speaker & Talk/text \\
\hline (1) & $\begin{array}{l}\text { Norbert } \\
\text { (teacher) }\end{array}$ & $\begin{array}{l}\text { Do we have to do this in our daily practice? Well, we } \\
\text { can look at it, sure, but to use them [the results] in our } \\
\text { teaching, well, I don't know about that. (Leaning } \\
\text { backward, with the arms crossed over the chest) }\end{array}$ \\
\hline (2) & $\begin{array}{l}\text { Hedvig } \\
\text { (teacher) }\end{array}$ & $\begin{array}{l}\text { But this will only be relevant regarding the students } \\
\text { with extremely poor results, right? Regarding } \\
\text { assignments that are extremely bad? }\end{array}$ \\
\hline (3) & $\begin{array}{l}\text { Asmund } \\
\text { (deputy) }\end{array}$ & $\begin{array}{l}\text { (Pointing at the smart board, ignoring the question } \\
\text { from Hedvig and Norbert) Here, you can see a } \\
\text { reversal of the prefix [looking into one particular } \\
\text { student's results in the numeracy test], we can see a } \\
\text { poor understanding of equating, and at least, it might } \\
\text { be useful to have a retest. Plus, if we use the teacher's }\end{array}$ \\
\hline
\end{tabular}




\section{Transcript \\ line \\ Speaker Talk/text}

guide... So each one of you must check the results of your students, and make a record of them... and then it's... we should spend more time to sit down with the class... but it could be that Gina plans differently than what she first said, but we should sit down and create questions to... eh. yes, for each student, and investigate at what level they are in reading and numeracy

(4)

Norbert Do we have allocated time for this? We have other (teacher) important things to do, if I may dare to say so...

Åsmund (deputy)

I don't know. I have to ask Gina

In the above talk, Åsmund transfers principal Gina's demands to the teachers. Åsmund's effort as a facilitator is undermined when Norbert asks about the use of time. Norbert maintains the role of critic and upholds the counter-discourse. Assmund, however, tries to couple the roles of narrator, entrepreneur, and enthusiast by using "we" when he demonstrates how to use the test results (3). This attempt fails when he says that he has to "ask Gina" (5) because Åsmund places himself in a position with the teachers: the receivers. Only one teacher plays the lead part as a critic openly, while the other teachers passively support him.

At Blue Mountain, the focus on national test results is absent when it comes to direct initiatives to discussions in the teacher-team meetings. However, the principal holds a discursive role as the initiator of issues to be discussed. The difference seems to be in the initiating role and not the demanding role. At Blue Mountain, the issues are related to basic skills with a regular focus on reading instruction, numeracy instruction, and teaching practice. In the next excerpt (Table 13), the teacher Maria leads the teacher-team meeting. At Blue Mountain, leading the meeting is a task which rotates every week. Maria begins by reading notes from the leaderteam meeting, and the excerpt focuses on the initiating role of the school leaders and how the initiatives are interpreted in the teacher-team meeting.

\section{Table 13}

The preventers of overburdening at Blue Mountain

\section{Transcript Speaker Talk/text}


line

\begin{tabular}{l|l} 
Maria & (teacher)
\end{tabular}

Today it has been initiated that we shall discuss how we identify the students who have not benefited satisfactorily from regular teaching at our school. I believe we have a kind of intuitive practice in this, but we do not actually have a system. My experience is that we are quite good at this, but it is perhaps sort of subconscious. Well, I mean, is it conscious, everything that the teachers do, which is about our practice over all. It is just like something that we always do. Then again: What are we actually doing?

This raises an interesting discussion. Given the time we have-we, the teachers - that we should spend on real school matters.-And we struggle with the

(2) Bergljot students that doesn't do what they should do-to (teacher) learn. And if we will follow up and think that we will have all students 'with us'-all the time and effort in every instruction period over and over again, ... what do we have left of time then?

\begin{tabular}{|c|c|c|}
\hline (3) & $\begin{array}{l}\text { Aslak } \\
\text { (teacher) }\end{array}$ & $\begin{array}{l}\text { Yes, because I have students that I think are never } \\
\text { going to understand all that we want them to }\end{array}$ \\
\hline (4) & Synne & $\begin{array}{l}\text { Yes, I agree there. And maybe we cannot get them all } \\
\text { with us? It is easier to be a student at our school for } \\
\text { those who are mature. It is no doubt about it }\end{array}$ \\
\hline$(5)$ & $\begin{array}{l}\text { Aslak } \\
\text { (teacher) }\end{array}$ & $\begin{array}{l}\text { Shall we discuss what learning is? Now? Is that what } \\
\text { is initiated? }\end{array}$ \\
\hline (6) & $\begin{array}{l}\text { Bergljot } \\
\text { (teacher) }\end{array}$ & $\begin{array}{l}\text { [...] I think it steals part of the planning period we } \\
\text { have. It's actually very rare that we have the time to } \\
\text { sit all together like we do now. I don't approve of the } \\
\text { fact that the leadership-team shall occupy the time } \\
\text { and expand the joint meeting in a way }\end{array}$ \\
\hline (7) & $\begin{array}{l}\text { Synne } \\
\text { (team } \\
\text { leader) }\end{array}$ & $\begin{array}{l}\text { Yes, I just have to say that we have asked about this } \\
\text { earlier, too. That we must also make the common } \\
\text { space for these discussions. And I am asked to do this } \\
\text { with you. Now }\end{array}$ \\
\hline (8) & $\begin{array}{l}\text { Bergljot } \\
\text { (teacher) }\end{array}$ & Yes, it is simply stealing our time \\
\hline
\end{tabular}

As Maria introduces the initiative from the leader team (1), the binary between 'them' as the leaders and 'us' as the teachers is not as apparent as at Brown Hill. Bergljot (2) turns the issue over to a matter of time and how difficult it is to know whether all students are benefitting from the instruction practice. Synne agrees with her (4). Aslak (5) asks what they are supposed to discuss, when Bergljot (6) repeats the issue of time use. Synne partly agrees (7) but holds on to the fact that she is asked to conduct 
this discussion in the teacher-team meeting as well.

The above instance of talk is an example of the tension between school leaders and teachers as policy actors and how their discursive roles are being used to negotiate organizational legitimacy. What is of special interest is that this negotiation occurs in different arenas and with different actors holding the main roles and the power. The teacher-team leaders and the deputy managers function as negotiators, enforcers, and messengers, and the principals as enthusiasts which, through the deputy managers and teacher-team leaders, appeal to the teachers. The teachers, in turn, are receivers and critics responding in meetings with the 'messenger.'

However, the receiver roles hold a different kind of power than the formal leadership roles, as the receivers in fact can decide whether to discuss the introduced matter or not.

\section{Discussion}

The aim of this article has been to identify and discuss the discursive processes in policy enactment at the local school levels. The analysis has focused on how school leaders and teachers constructed responses to new policy expectations, how they talked, and how they positioned themselves in meetings. The discussion is organized around the two research questions: (a) How do school leaders and teachers position themselves in their interpretation and translation of national testing policies? (b) In what ways does school leaders' and teachers' language reflect their enactment of national testing policies? In the following section, I will scrutinize the research questions to condense the description of findings related to each research question in combination with existing literature.

\section{Negotiation and positioning}

The most direct observation of positioning in the meetings occurred when the participants discussed the practicalities of conducting the tests. The notion of 'we' and 'them' was prominent. The data revealed sensitive viewpoints in what Fairclough (1992) defined as "intertextuality" (p. 270). The way school leaders and teachers positioned themselves during the meetings in their interpretation and translation regarding teacher instruction in basic skills and assessment practices indirectly addressed the meaning of national testing policies in general. The talk in the meetings 
illuminated competing discourses and power relations, and can be related to accountability studies which have shown that teachers' and leaders' collaboration with colleagues at all organizational levels influences how they interpret, adapt, and enact policy messages in the school and the classroom (Coburn 2001; Spillane 1999). In these two cases which are part of a low-stakes context, the participants seemed to sense and respond to the power relations. The power dynamics/positioning in the conversation, which can be called 'power talk', occurs both with the teachers and the leaders, either with the defending talk or the initiating talk. For example, the issue of time-use equally competed with the principals' and teachers' understanding of whether work with national test results was equivalent with other tasks on the agenda. This finding highlights how leadership as a relational process always involves some sort of influence and includes the exercise of power (cf. Gronn 2002; Liljenberg 2015; Sørhaug 1996).

Moreover, another power issue was illustrated in the way the formal leaders occupied what I would call the 'talking space' in the meetings, even when they were not present. In turn, the teachers, teacher-team leaders, and deputy managers allowed the formal leader to take this space. It is evident that power relations were dominant and the dynamics of power and leadership varied within the different levels in the local school. The hierarchy and the formal power of the principals seemed to be consistent. The teachers at Blue Mountain bought into the school's collective vision, while this was not the case at Brown Hill. Second, the data from the two schools demonstrated how work with national test results can develop in different directions. This divergence may relate to leadership strategies and to the culture and schools' history that has been established over time. This finding demonstrates that context matters (Ball et al. 2012). The diverging directions could also be explained by understanding leadership as a personal and relational dimension (Sørhaug 1996).

Positioning oneself, negotiation of power, and the interpretation and translation of national testing policies were prominent both in the leaderteam meetings and the teacher-team meetings. In the teacher-team meetings, the negotiation was primarily about practicalities which also can be understood as the translation of policies. In the leader-team meetings, the negotiation centered around how to understand the new policy expectations, which can be understood as the interpretation of policies. 
However, both the interpretation and the translation processes were part of how the school leaders and teachers aimed to put policies into practice (Ball et al. 2012). What is of importance in this finding is that, within the policy work, the negotiation and performance of power happened in different arenas without all the policy actors being present physically. In the 'delivery work' between the two meeting arenas, the principals' interpretation somehow seemed to be 'lost in translation,' in particular at Brown Hill.

The policy expectation of using national testing as a tool to develop school quality and student learning was not actually fulfilled during the negotiation and positioning. The data from national testing may inform policymakers at the system level, such as by providing local educational authorities with information about how students perform in the basic skills in general. However, to achieve the policy expectation that the national test results will contribute to school development, it is necessary to combine national policy intentions with broader dialogue and support regarding local school practice and student performance (Datnow 2002). Few would argue that students should potentially benefit academically from standardized achievement tests. The potential benefit, hence, may develop from the meaning that teachers make from scrutinizing the test results with an emphasis on enhancing individual student learning. Other measures of success might also address whether a reform or policy initiative leads to long-term school improvement, student learning, and teacher development, or whether it hinders such efforts (Datnow 2002, p. 233).

\section{The power of language}

An important finding was the focus on the how and not so much on the why of the issues being discussed (Fairclough 2003). In the leader-team meeting, particularly at Blue Mountain, the discussions centered on both practicalities and justification for the school's practice. The fact that they recorded every single meeting from mid-August throughout October points to their attempt at justification. Brown Hill chose to video record only the meetings with national tests on the agenda. Even so, their collaborative talk about national tests was hardly present, and the justifications for the school practice were matched by practicalities. Practicalities may be ways of clearing space for teachers to spend more time conducting translation work in other arenas. Hence, the language and the talk of the preventer of 
overburdening plays a key role in this "policy work" (Ball et al. 2012, p. 49), and the issue of time seems to be a part of the policy discourses and one of the "ways of talking about and conceptualizing policy" (p. 109). Policy discourse is both construction and understanding of texts in that the texts are inseparable and related to action and enactment (Gale 1999). The discourses on 'student learning' and 'school quality' therefore seem to be both separate and coinciding with the discourse on time. However, it might also be possible that the language of the testing policy is internalized by the participants with the result that a focus of their talk on practicalities represents a kind of capitulation to the testing policy. In such circumstances, it is more comfortable, less confrontational, to focus on practicalities as a form of compromise, or evidence of their 'better judgement' and the values they espouse, actually being compromised.

Of importance in the findings was how language and discursive parts were used to make apparent the power exercised though the chains of these events (Fairclough 2003). In this case, the 'chains of events' were represented by teacher-team meetings and leader-team meetings throughout and between the recorded meetings. The language of the formal school leaders appeared to help in translating and narrating national policies meaning to be transferred from leader-team meetings to the teacher-team meetings. The school leaders directly or indirectly introduced to the teachers their individual interpretation of policy texts, expecting them to adapt their interpretation. The formal school leadership role contested with the power of the preventers and critics. These findings illuminate the dilemmas of top-down steering versus self-governing (Cuban 1996; Møller 1994). For example, implementing central principles stated about the use of national test results is not a straightforward task because the two principals most probably know that they cannot satisfy all the staff members all the time. Referring to Ball et al. (2012), this can be explained as interpretations and translations of policy occurring in different arenas, contexts, subjects, and school cultures. The interpretation and translation are in turn critiqued or received by the teachers as they either accept or cope with the policy while protecting and preserving their current practice (Ball et al. 2012).

\section{Leadership strategies}

A visible strategic and hierarchic leadership was prominent in the 
discursive roles of both the principals, although in different ways. While Gina took an authoritative direct role in her talk with the teacher-team leaders and mainly instructed the teachers to do what she wanted, Rebecca used more indirect leadership strategies. However, both principals emphasized the focus on low-performing students. One explanation might be that the comprehensive education system in Norway is strongly rooted in ideologies and norms, emphasizing aspects of equity that are linked to social-democratic values (Møller et al. 2007; Ottesen and Møller 2016). In this case, both principals emphasized the students who seemed to need the most help. Ball et al. (2012) asserted that policies hardly inform school actors exactly what to do; in fact, they barely dictate or determine practice. Some policies may narrow the range of creative responses. The school leaders' talk in Tables 5 and 6 illuminated the power when the school leaders narrated, negotiated, and interpreted how policies can be understood and how decisions are being determined. These conversations also illustrated the power of the principals.

These findings might differ from high-stakes accountability contexts where practitioners experience stronger external pressure. In the typology developed in high-stakes testing regimes (Ball et al. 2012), there is no mentioning of policy actors taking a monitoring or an evaluating role. Rebecca referred to research and theory when discussing the matter of student learning and teacher practice in the leader-team meeting. Gina referred to policy texts when demanding teacher action for improving student learning by making use of the national test results. Both principals used their positions of power by dominating the degree of talk in the meetings, aiming to set directions and/or build consensus with the teachers. They were similarly visible in their expectations, but in different ways. The findings of the principals' discursive roles may be explained by examining the contextual history of the local schools, where Blue Mountain has a long history of collaborative culture. Rebecca was recruited as principal after having been a teacher there for many years; hence, she had good knowledge of the culture. This might explain why she chose a more indirect strategy. Gina had been recruited from another school and was not as embedded in the established culture as Rebecca. The two schools' history and culture also might explain why the teachers attributed the translation and negotiation of policy expectations differently. 


\section{Concluding remarks}

This study aimed to identify and discuss the discursive processes in policy enactment at the local school level. The findings have shown how the principals acted as narrators and enthusiasts to encourage productive processes. Deputy managers were somehow squeezed in the middle, and some prominent teachers acted as critics of the new policy. In summary, this study has contributed to knowledge of how policy is transformed at the local school level and how policy negotiation and translation may take unpredictable forms. The outcome in terms of experiencing national test results as a tool for improving schools and student learning is not necessarily as the local and national authorities would expect. On the contrary, the expectations seem to be lost in translation.

A suggestion for future research is to examine how the roles and the power performed on the local school level may affect the translation and negotiation processes and, in turn, the work with improving teacher practice and student learning. Moreover, policymakers and superintendents may need to involve schools (school leaders and teachers) in a dialogue about new policy expectations to create optimal conditions for the development of these schools. However, such conversations across school levels may also imply less spaces and opportunities for debate, dissent and resistance at the local school. Well-informed policy expectations might encourage school leaders and teachers to take active part in discussions about the purposes and local practices around large-scale student test results.

Lastly, some limitations of the study should be mentioned. Even though the study included on-site observation and video recordings of meeting practices to understand the historical and cultural aspects in processes of translation and negotiation of policy expectations, more comprehensive observations of practices in other situations in the local schools are needed. This would probably enrich the current research base on policy enactment.

\section{References}

Aas, M., Brandmo, C., \& Bryant, D. (2016). Revisiting instructional and transformational leadership: The contemporary Norwegian context of school leadership. Journal of Educational Administration, 54(1), 
$92-110$.

Aasen, P., Prøitz, T., \& Rye, E. (2015). Nasjonal læreplan som utdanningspolitisk dokument. [National curriculum as educational policy document]. Norsk pedagogisk tidsskrift, 99(6), 417-433.

Anderson, S., Leithwood, K., \& Strauss, T. (2010). Leading data use in schools: Organizational conditions and practices at the school and district levels. Leadership and Policy in Schools, 9(3), 292-327.

Ball, S. J. (1994). Education reform: A critical and post-structural approach. Buckingham: Open University Press.

Ball, S. J., Maguire, M., \& Braun, A. (2012). How schools do policy: Policy enactments in secondary schools. London: Routledge.

Caldwell, K., \& Atwal, A. (2005). Non-participant observation: Using video tapes to collect data in nursing research. Nurse Researcher, 13(2), $42-54$.

Coburn, C. E. (2001). Collective sensemaking about reading: How teachers mediate reading policy in their professional communities. Educational Evaluation and Policy Analysis, 23(2), 145-170.

Cuban, L. (1996). Reforming the practice of educational administration through managing dilemmas. In S. L. Jacobson, E. S. Hickcox, \& R. B. Stevenson (Eds.), School administration: Persistent dilemmas in preparation and practice (pp. 3-17). London: Praeger.

Datnow, A. (2002). Can we transplant educational reform, and does it last? Journal of Educational Change, 3(3-4), 215-239.

Diamond, J., \& Spillane, J. (2004). High-stakes accountability in urban elementary schools: Challenging or reproducing inequality? The Teachers College Record, 106(6), 1145-1176.

Fairclough, N. (1992). Intertextuality in critical discourse analysis. Linguistics and Education, 4(3-4), 269-293. 
Fairclough, N. (1995). Critical discourse analysis. The critical study of language. In Language in social life series. Harlow, UK: Longman. AQ4

Fairclough, N. (2003). Analysing discourse: Textual analysis for social research. London: Routledge.

Fairclough, N. (2013). Critical discourse analysis: The critical study of language. London: Routledge.

Foster, W. (1986). The reconstruction of leadership. VIC: Publication Sales, Deakin University Press.

Gale, T. (1999). Policy trajectories: Treading the discursive path of policy analysis. Discourse: Studies in the Cultural Politics of Education, 20(3), 393-407.

Gee, J. P. (2014). An introduction to discourse analysis: Theory and method. London: Routledge.

Gronn, P. (2002). Distributed leadership as a unit of analysis. The Leadership Quarterly, 13(4), 423-451.

Hall, D. (2013). Drawing a veil over managerialism: Leadership and the discursive disguise of the New Public Management. Journal of Educational Administration and History, 45(3), 267-282.

Hardy, I. (2014). A logic of appropriation: Enacting national testing (NAPLAN) in Australia. Journal of Education Policy, 29(1), 1-18.

Ingram, D., Seashore Louis, K., \& Schroeder, R. (2004). Accountability policies and teacher decision making: Barriers to the use of data to improve practice. The Teachers College Record, 106(6), 1258-1287.

Jørgensen, M. W., \& Phillips, L. (1999). Diskursanalyse som teori og metode. [Discourse analysis as theory and method]. Frederiksberg C: Roskilde Universitetsforlag.

Kvale, S., \& Brinkmann, S. (2009). Interviews: Learning the craft of 
qualitative research interviewing. Los Angeles, CA: Sage.

Liljenberg, M. (2015). Distributed leadership in local school organisations. Working for school improvement? (Doctoral dissertation). University of Gothenburg, Sweden.

Lincoln, Y. S., \& Guba, E. G. (1985). Naturalistic inquiry (Vol. 75). London: Sage.

Lindblad, S., Johannesson, I. A., \& Simola, H. (2002). Education governance in transition: An introduction. Scandinavian Journal of Educational Research, 46(3), 237-245.

MacLure, M. (2003). Discourse in educational and social research. Buckingham: Open University Press.

Mausethagen, S. (2013). A research review of the impact of accountability policies on teachers' workplace relations. Educational Research Review, 9, 16-33.

Mausethagen, S., \& Granlund, L. (2012). Contested discourses of teacher professionalism: Current tensions between education policy and teachers' union. Journal of Education Policy, 27(6), 815-833.

Mausethagen, S., Skedsmo, G., \& Prøitz, T. (2016). Ansvarliggjøring og nye organisasjonsrutiner i skolen - rom for læring? [Emerging accountability and the introduction of new organisational routines in the school system: Room for learning?]. Nordiske organisasjonsstudier, 18(2), 79-97.

Maxwell, J. A. (2012). Qualitative research design: An interactive approach. Los Angeles, CA: Sage.

McCambridge, J., Witton, J., \& Elbourne, D. R. (2014). Systematic review of the Hawthorne effect: New concepts are needed to study research participation effects. Journal of Clinical Epidemiology, 67(3), 267-277.

Mintrop, H., \& Sunderman, G. L. (2009). Predictable failure of federal 
sanctions-driven accountability for school improvement-And why we may retain it anyway. Educational Researcher, 38(5), 353-364.

Møller, J. (1994). Lare å lede: dilemmaer i skolehverdagen [Learn to lead: Dilemmas in everyday school]. Oslo: Cappelen Damm Forlag.

Møller, J. (2009). School leadership in an age of accountability:

Tensions between managerial and professional accountability. Journal of Educational Change, 10(1), 37-46.

Møller, J., Eggen, A., Fuglestad, O. L., Langfeldt, G., Presthus, A. M., Skrøvset, S., et al. (2007). Successful leadership based on democratic values. In C. Day \& K. Leithwood (Eds.), Successful principal leadership in times of change (pp. 71-86). Dordrecht: Springer.

Møller, J., \& Skedsmo, G. (2013). Modernising education: New Public Management reform in the Norwegian education system. Journal of Educational Administration and History, 45(4), 336-353.

Norwegian Directorate for Education and Training. (2011). Nasjonale prøver. Veiledning for skoleeiere og skoleledere [National tests. A guide for superintendents and school leaders], Oslo, Norway.

Ogawa, R. T., \& Bossert, S. T. (1995). Leadership as an organizational quality. Educational Administration Quarterly, 31(2), 224-243.

Ottesen, E., \& Møller, J. (2016). Organisational routines-The interplay of legal standards and professional discretion. European Educational Research Journal, 15(4), 428-446.

Ozga, J. (2009). Governing education through data in England: From regulation to self-evaluation. Journal of Education Policy, 24(2), 149-162.

Porter, S. (2007). Validity, trustworthiness and rigour: Reasserting realism in qualitative research. Journal of Advanced Nursing, 60(1), 79-86.

Robinson, V. (2011). Student-centered leadership (Vol. 15). San 


\section{Francisco, CA: Jossey-Bass.}

Sørhaug, T. (1996). Om ledelse: makt og tillit i moderne organisering [About leadership: Power and trust in modern organizing]. Oslo: Universitetsforlaget.

Spillane, J. (1999). External reform initiatives and teachers' efforts to reconstruct their practice: The mediating role of teachers' zones of enactment. Journal of Curriculum Studies, 31(2), 143-175.

Timperley, H. (2011). Knowledge and the leadership of learning. Leadership and Policy in Schools, 10(2), 145-170.

Yin, R. K. (2009). How to do better case studies. The SAGE Handbook of Applied Social Research Methods, 2, 254-282.

In this study, the concept of school leadership means all formal leadership positions in schools (e.g., principal, deputies, teacher-team leader, and department head). All names are anonymized.

3 In a Norwegian context, the municipalities act as local educational authorities.

4

In this study, the title deputy manager is given to those with formal responsibilities associated with the former assistant principal role. The deputy managers are responsible for managing subject matters and human resources in 'their' grade levels, including economic responsibility for parts of the school's budget.

5 Such observation was not possible to do at Brown Hill.

6

The recordings and observations were made in Norwegian, and the translations of transcribed texts are mine. 